Published by the University of KwaZulu-Natal https://journals.ukzn.ac.za/index.php/JICBE

(C) Creative Commons With Attribution (CC-BY)

Journal of Inclusive cities and Built environment. Vol. 1 Issue 2

How to cite: Abd'Razack et al., 2021. Comparative Analysis of Ecological Footprint of Urban and Rural Households in Minna Emirate of Niger State, Nigeria. Journal of Inclusive cities and Built environment. Vol. 1 Issue 2, Pg 41-54.

\title{
COMPARATIVE ANALYSIS OF ECOLOGICAL FOOTPRINT OF URBAN AND RURAL HOUSEHOLDS IN MINNA EMIRATE OF NIGER STATE, NIGERIA
}

\author{
By Abd'razack, N.T.A, Medayese, S.O., Martins, I.V and Idowu, 0.0
}

Published 25th October 2021

\begin{abstract}
Nigeria is an unsustainable country due to an ecological deficit arising from the excessive utilization of natural resources. Resources are consumed more than their bio-capacity. Lifestyle and variation in the needs of households have exerted demands on the natural resources and eventually on the global environment. This research therefore aimed at estimating the Ecological Footprints of the average individual in a household in the urban and rural areas of the Minna region in Nigeria. It identifies the types of resource consumption; the impact of consumption on the EF and compares the EF of both about the level of sustainability. Data were collected employing primary and secondary sources for the study. A total of 400 households was selected for the study. Questionnaire administration was employed to collect the data and random sampling was employed. The data were analyzed through explanatory and inferential statistics. The result of the study shows that the EF of Minna and Maikunkele were 1.10 and $0.892 \mathrm{gha}$. Households require an average of 0.91 and 0.74 planets to sustain their living standard and generate 6.2 and 4.3 tonnes of $\mathrm{CO} 2$ annually. 9 and 6 factors influence EF. It is recommended that the lifestyle of the household in the Minna region has to be modified to reduce pressure on environmental resources and the emission of GHG for sustainable development.
\end{abstract}

KEY WORDS Ecological Footprint; Urban, Rural, Resources; Bio-Capacity; Consumption

Abd'razack, N.T.A, Medayese - Department of Urban and Regional Planning, Legacy University, Banjul, The Gambia Corresponding author email: n.abdrazack12310@yahoo.com

S.O., Martins, I.V and Idowu, O.O - Department of Urban and Regional Planning, School of Environmental Technology,

Federal University of Technology, Minna, Nigeria 


\section{INTRODUCTION}

Growing human population and urbanization have created the forceful force to the natural resources exploitation for the livelihood of mankind and utilization. The environment has constantly played the role of provider of natural resources and absorber of the waste generated by people's behaviour while consuming the natural endowments GFN [1]. Norbet and Peter [2] in their study revealed that a vast proportion of people living on earth at present are in urban areas that continue to grow unabated. This assertion was corroborated by research conducted by UN-Habitat and reported that $50 \%$ of the world's population lives in cities and towns. This landmark was achieved in 2007 UN-Habitat [3]. Research has established that cities and towns in the world account for only $2 \%$ of the global land areas. Therefore the urban population has enormous effects on the environment because it is the centre for utilization of natural resources in the excess of $75.0 \%$ Norbet and Peter [2]. The consequence of this is the excessive pouring of carbon dioxide into the atmosphere. Greenhouse Gases account for $80.0 \%$ of the world's global warming phenomenon Norbet and Peter [2]. Urbanization has resulted in ecological deficits, the ecosystem has been replaced with an artificial environment as a result of excessive utilization of natural resources. As a result, cities and metropolitan areas are playing a significant role in destroying the flora and fauna available in the environment that nature endows us with.

The relationship between human beings and nature is expected to be symbiotic, but the reverse is the case as the man had modified nature for its sustenance [2]. These are the erstwhile reasons why biodiversity is being exhausted and the world's capabilities to replenish the natural stock [GFN, 1]. The sustenance of human existence is proving to be problematic globally. Persistent increase in urban population has far-reaching consequences on the ecosystem (Abd'Razack, 2014). The environmental consequences of urban growth is a concern for conservationist in sustainability paradigm. City region devours almost all the environmental resources nature endow us with and produces waste (which is both eco-friendly and non-eco-friendly). Figure 1 is the authors expression of the scenario in an urban setting. This illustration shows the resources consumed and waste generated in cities. The urban area is the foundation for ecological deficits that are ravaging the world as a result of man's actions 9Abd'Razack, 2014]. The urban regions inhabited modest landmass globally and the pressure exerted by tremendous population demonstrates tall, financially viable, communal, civilizing, and opinionated relationships that influence the natural settings. The utilization of resources (either natural or man-made) by man can either be obtained locally or from abroad far from the city region's geographical boundaries [UN, 3]. This might creates divisions connecting production and consumption of natural resources due to the consequential effects of people's lifestyles.

Figure 1: System process of Resources Consumption in the City Region

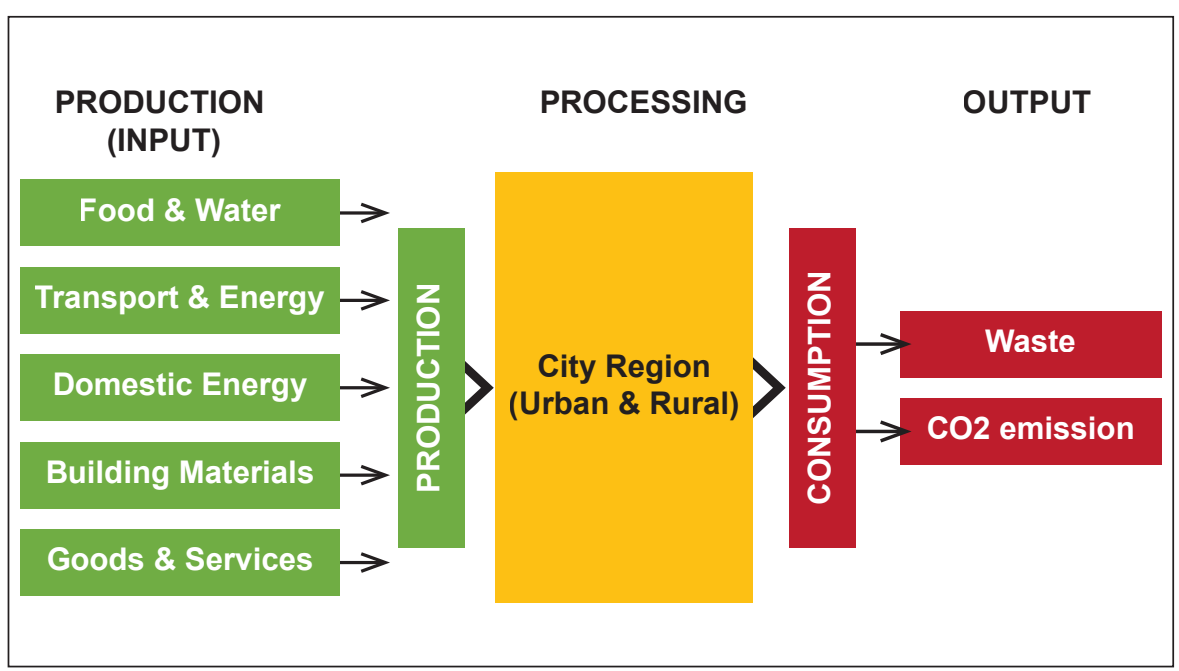

Source: Adapted with modification from EPSM [4]; GFN [1]; Newman [5]

Several techniques had been developed for measuring the sustainability of the world, nations, and urban areas (Abd'Razack, 2014). Amongst the techniques employed for measuring sustainability is Ecological Footprint (EF). The term 'Ecological Footprint' $E F$ is defined as "the land area that would be needed to meet the consumption of a population and to absorb all their waste" Wackernagel and Rees [6]. The concept of EF was propagated as a tool for measuring sustainability by Rees and Wackernagel in their research conducted in 1994. Though Rees and Wackernagel popularised $E F$, it is a phenomenon that originated as early as the 18th century by Malthus classical economics based on population and economic development. The research conducted by Wackernagel and Rees detailed the idea of carrying capacity that is the guiding principle of sustainable development worldwide. EF, therefore, becomes a vital tool for analysing sustainability and sustainable development. The major function of Ecological Footprint (EF) is an estimation of demand that man placed on the global bio-capacity of the earth.

Ecological Footprint is a parameter to measure man's lifestyle, utilization system, and ecological consciousness in the process of consumption of natural resources; hence, this research intends to illustrate the relationship between consumption (both natural and artificial resources) and the lifestyle of man. This is a measure of sustainable development that the world is grappling with at present. EF as an analytical tool indicates natural resources utilization in a specific urban area, that is beyond the geographical and political boundaries of such cities Ayres [7]. It is important, therefore, to consider the urban centre as a region rather than a solitary unit. The sustainability 
of a city needs an amalgamation of ecological management; communal fairness and economic benefits in decision-making. The procedure of measuring sustainability requires the knowledge of resource consumption, waste management, $\mathrm{CO} 2$ and Greenhouse gas (GHG) emission, and employment of technology to understand the present and future generations' need (Bagliani et al [8]. It is a known fact that man's activities are solely responsible for the problems bedeviling the environment. The environmental problems had affected man's life and in the long run affect future generations as well. The environmental problems have manifested in a variety of ways such as air, water, and land pollution, climate change global warming and melting of polar ice, Greenhouse Gas emissions (GHG's), and rising sea level Wiedmann [9]; Holden [10].

It is therefore a prerogative of urban planners to understand man's utilization of the environment. The Rio 1992 and Rio +20 summit warn that population explosion and lifestyle is the major factor confrontation the environment and natural resources in the 21st century. The present consumption pattern is more unsustainable due to depletion of natural resources, aggravation of poverty level and loss of flora and fauna in the ecosystem, clean water deprivation, vegetation depletion, and generation of non-biodegradable wastes Abd'Razack et al. [11].

If sustainability is to be achieved, the world's carrying capacity has to ensure that the urban dwellers consume optimally both natural and man-made resources in such a way that the limit of its capacity is not exceeded. The pressure placed on the global resources at present is beyond the carrying capacity of the world (Rees and Wackenagel, 1996). Therefore, the challenges posed by sustainability to the world is how the world population will sustainably adjust their lifestyle to resources utilization and reduces the pressure on the world's ability to regenerate Wackernagel [12]. Hence there is a need to correlate the population's perception on ways to ensure proper utilization of resources with the standard of living and quality of life.

EF analysis, therefore, links sustainability with resource utilization and natural resources endowment Holden [10]. The process of estimating employed by EF is centered on two important realities: foremost, resources, production and consumption can be followed and records kept for utilization and generation of waste; secondly, calculating and estimating the exact bio-productive land area needed for such activities. Therefore, EF explains the process of resource utilization by countries. According to Ewing et al. (2010); Wackernagel et al. [18], the global Ecological Footprint of humanity and bio-capacity is based on six assumptions: consumption and waste generated can be estimated and measured; Bio-productive land area can be measured in global hectare (gha); the flow of resources can be calculated as bio-productive land area; the size of 'global hectares' correspond to an equal measure of the quantity of exploitable biomass production in a given year; natural resources of the environment could be articulated as the bio-productive land area in global hectare and land area that is needed might be more than the bio-productive land area accessible and utilized.

Therefore, it implies that ecological consumption may exceed the regenerative capacity of the ecosystem causing 'ecological overshoot'. Wackernagel et al. [19]; Kitzes et al. [20]; Ryan [21], all agreed that the Ecological Footprint Analysis is the process of estimating the entire components that make up the EF (cropland, carbon land, grazing land, fishing ground, built-up area, and forest land) and these demand and supply components are summed up together which give an aggregate EF. The global EF was estimated at an average of 2.5 gha/capita and when summed up with the 7.2 billion world population, it amounts to 18.1 Billion gha.
On the other hand, the global biological productive land area in the world is 12 Billion gha (translating to $1.7 \mathrm{gha} /$ capita) in 2015 GFN [22]. On the other hand, the national EF of Nigeria was estimated at 1.44 gha/capita and Bio-capacity at 1.21 gha/capita. It implies that the country is not sustainable at this rate, because its EF is higher than its Bio-capacity.

Nigeria had urbanised and is still urbanising and the National Population Commission NPC [23] estimated the population to be 140.4 million in 2006 with an annual growth rate of $3.2 \%$. This implies that the population is 205.03 million in 2019. Nigeria is then an ecologically susceptible country because the resources utilization is more than what the ecology can reproduce. Nigeria is located geographically in the heart of Africa and paradoxically presented contrasting phenomenon "the country is rich and the people are poor" (UN, 1996). The socio-economic weakness of the country had made it susceptible to social problems, economic cul-de-sac, and environmental degradation.

As unique as the EF is, it is observed that EF didn't show degradation and exhaustion that is ravaging the world, rather it present the extent of resources utilization and manners to reduce consumption (Wackernagel \& Rees [13]; Adams [14]; Dobson [15]. The underlying principle behind estimating EF is shown to the world's population, the consequences of their lifestyles, and sustainability. EF also indicated to the policymakers the process of sustainability within the carrying capacity of the world, but does not imply the improvement in technology as a factor that enhances sustainability. It is also criticized that it only shows how to reduce the effect of environmental degradation, pollution, and other environmental problem due to o consumption but failed to see progress being made in the field of sustainable development for the present and future generations Abd'Razack [16]; Oloruntegbe et al. [17]. 
The Global Footprint Network GFN [22] report indicated that Nigeria is part of the countries in the world that are deficient, ecologically. This implies that consumption consumption of its natural resources is more than its biologically regenerative potentials. The ecological deficit is $0.23 \mathrm{gha} / \mathrm{capita}$ as indicated by GFN (2018). The EF was estimated at 1.44gha and Bio-capacity was estimated at $1.21 \mathrm{gha}$. Statistics always show mean rather than reality. An individual lifestyles that can consume more than the average Ecological Footprint cannot be disaggregated when the mean EF was used for the analysis. The study of EF enables the researcher to estimate the consumption potential of the household to contribute to the EF of a nation, city, neighbourhood, therefore, this study estimates the EF and Bio-capacity potential (sustainability potentials) at household level in different region in the country. This study, therefore, intend to estimate the EF of the average household in urban and rural Minna region, and compared to the national EF, it has the following objectives:

- $\quad$ Estimating the EF of household in urban and rural Minna region and its Bio-capacity;

- $\quad$ Correlates the factors that influence EF of households in both urban and rural areas of the Minna region; and

- $\quad$ Calculating approximately the effects of diverse reasons influencing the EF of Minna region both urban and rural areas.

\section{STUDY AREA}

Minna emirate is located between Latitude 9037' and 9051'North and between Longitude 6033' and 6050'East of Greenwich Meridian (Minna Master Plan, 24). Minna emirate comprises Minna city and many rural settlements surrounding it. The linkage of the Minna emirate to various parts of Niger state is presented in Figure 2. Minna emirate is urbanization and growing at a higher rate than the national average $(4.8 \%$ compared with $3.2 \%$ national growth
NPC [23]. This has led to population explosions of urban Minna from a mere 95,000 in 1980 to about 390,108 in 2018 . Maikunkle village was mere 181 people in 1980 and it was estimated to be 11,178 in the same period. This inevitably increases consumption of natural resources in the city. Estimating the sustainability potential of urban Minna and comparing it with the neighbouring villages was done through measurement of their Ecological Footprint.

Minna Emirate is situated in the North Central region of Nigeria and is characterized by tropical savannah vegetation. The mean rainfall of the region is $1,334 \mathrm{~mm}(52.52$ inches). The peak of the precipitation is September (300 mm or 11.7 inches) and the average mean temperature ranges between $33 \circ \mathrm{C}$ and 27oC Master Plan [24]. Minna Emirate is located in the high humidity and low-pressure belt of Nigeria. The main challenges posed by the rapid urbanisation of the Minna Emirate include population explosion; traffic congestion and bottleneck; destruction of the ecosystem through poor waste management system; all forms of pollution (air, land, and water) Abd'Razack [16]. This enormous population explosion experienced in the last 20 years and high rate of urbanisation has been the driving force for the selection of Minna Emirate for the study.

Eigure 2: Map of Minna Region.

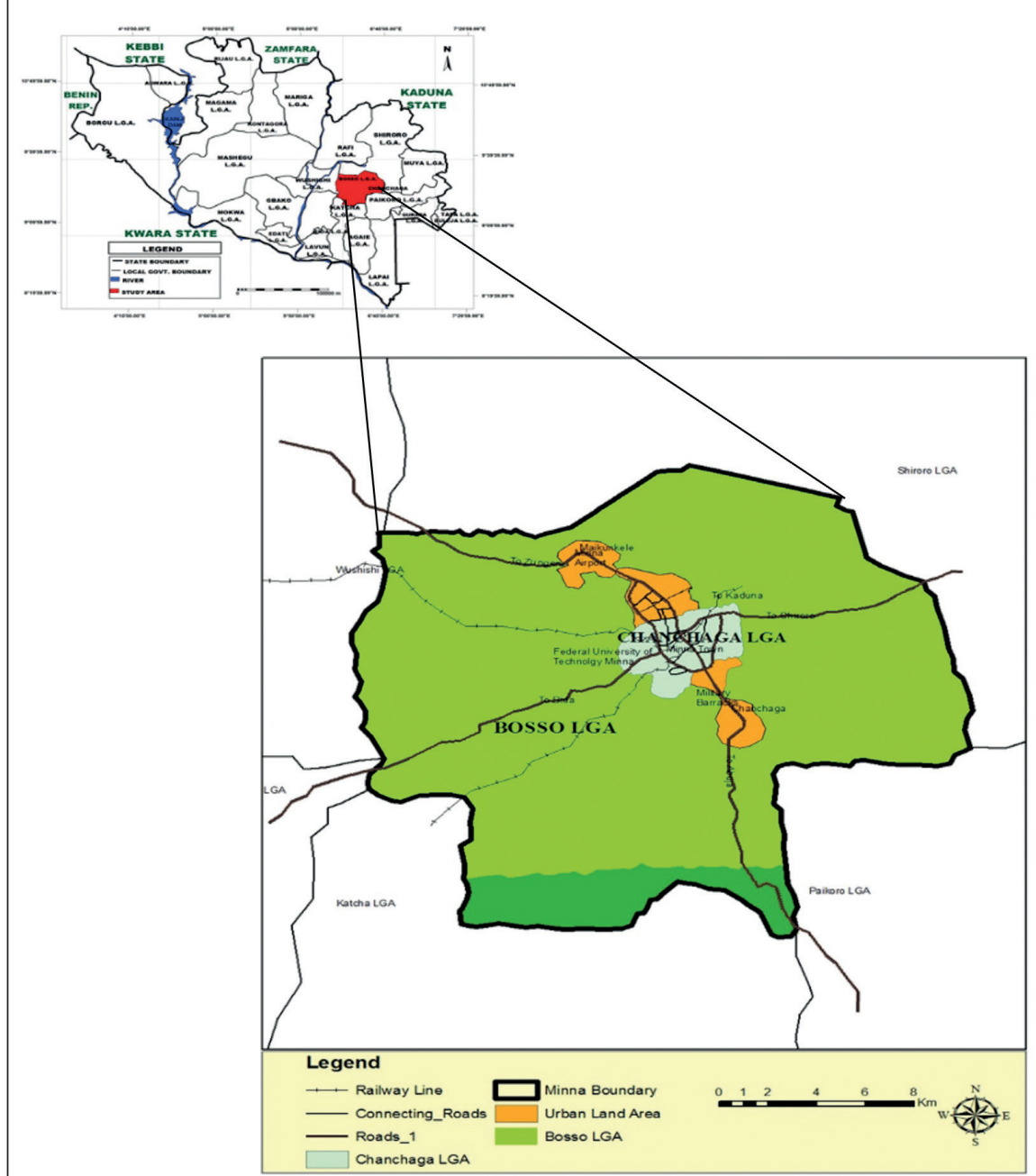




\section{METHODOLOGY FOR THE STUDY}

This study was carried out using empirical research that entailed structured questionnaire administration that ascertained the estimation of Ecological Footprint and a biologically productive land area of Minna Emirate. The procedure of estimating the Ecological Footprint of the Minna Emirate entails calculating the resource utilization by the people of the region. The process involves the estimation of the Ecological Footprint of Minna Emirate (both urban and rural) using the Ecological Footprint calculator to estimate the utilised resource that constitutes the Ecological Footprint by households (gha) and calculating the bio-capacity per capita (gha).

Estimating the Biological productive area of Minna Emirate also involves calculating the total bio-productive land areas available in the region, which include land types (arable land, pastureland, forest land, fishing ground, built-up land, and energy land) and multiply it with the equivalent and yield factor of the country (Nigeria). The Biocapacity is estimated by the use of the Consumption Land Use Matrix (CLUM). The sampling method was employed in two stages; the first stage involves stratifying Minna urban areas into six neighbourhoods and the rural Minna region is seen as one neighbourhood (Maikunkele village). Maikunkele village was used for the study amongst the many rural areas around Minna city because of its proximity, population size, and awareness of the residents to the study. Both primary and secondary data were employed for analysing the data collected from the questionnaire. The questionnaire was composed of eight parts-six parts for EF: housing, food, energy, transport, waste, and water, and two parts for socioeconomic and demographic characteristics. A stratified random sampling technique was employed for the study, this makes the questionnaire administration easy [Cresswell, 25] and simple random sampling was employed in the rural settlement because of the homogeneity of the population. A simple random sampling technique was employed to administer the questionnaire after the neighbourhoods had been divided into six strata. The household was used as a unit of measurement in the research. 400 households (388 in urban Minna and 12 in Maikunkele; a total of $6 \%$ of the total population) were sampled and serve as a sampling size of the study Cresswell [25] sample size. The structured questionnaire was a multiple choice type and was employed to guide the calculation of the research. The questionnaire was divided into 8 parts. The socio-economic status of households constituted the first part, section two to seven of the questionnaire asked questions on the six components of the EF, and section eight considered the environmental awareness and behaviour of the households in the region.

EF calculator and Consumption Land Use Matrix (CLUM) were employed to calculate the EF and Bio-capacity of Minna Emirate. Furthermore, SPSS software was employed for the descriptive, inferential, and regression analysis of the research. The analysis was presented in both tabular and pictorial forms. This model was used to estimate the total impact separately for urban and rural households.

\subsection{Econometric Modelling}

The impact of the influencing factors of household EF was conducted through an econometric model employing WLS. This was arrived at by combining all the household expenditure, socio-demographic characteristics, and monthly income.

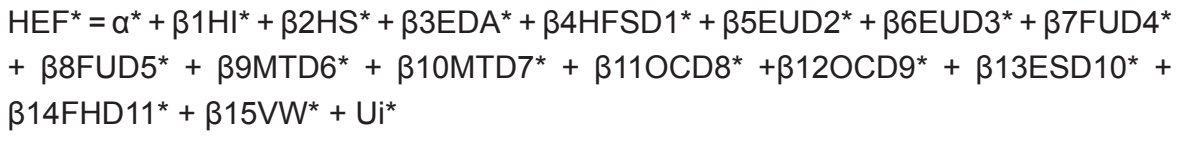

\section{WHERE}

HEF $=$ Household Ecological Footprint (gha)

UHEF = Urban Household Ecological Footprint (gha)

RHEF = Rural Household Ecological Footprint (gha)

$\mathrm{HI}=$ Household's Income per Month (N)

HS =Household Size

EDA $=$ Years of Education .

HFS =Housing Floor

$\mathrm{EU}=$ Energy Usage

$F U=F o o d$ Usage

MT = Mean of Transportation used by the households

$\mathrm{OC}=$ Occupation Types

$E S=$ Energy Sources for Heating by the households

VW $=$ Total Volume of Waste generated by the household $(\mathrm{Kg})$

Ui= Random term. 


\subsection{Sampling Frame and Size for the Study}

The population estimates and projection put the current population of the study area at about 398,286 and the population census estimated that 6 people per household make up a household, the number of households per localities was estimated. A sample of size 400 households ( $6 \%$ of the total population) was employed (388 for urban households and 12 for rural households) at the degree of freedom of $95 \%$ and the assurance ratio of $4 \%$. The respondents were selected randomly after the classification of the urban area into six neighbourhoods and one neighbourhood for rural areas. Table 1 shows the sample population and sample size for the study in each of the strata called neighbourhoods

Table 1: The Sample Size for the Study

\begin{tabular}{|l|l|l|}
\hline Localities & No of Households & Sample size \\
\hline Minna City Centre & 42,976 & 250 \\
Barkin Sale & 1,652 & 12 \\
Sauke Kahuta & 963 & 10 \\
Chanchaga & 6,557 & 40 \\
Bosso & 9,278 & 56 \\
Maitumbi & 3,092 & 20 \\
Mainkunkele & 1,863 & 12 \\
\hline Total & $\mathbf{6 6 , 3 8 1}$ & $\mathbf{4 0 0}$ \\
\hline
\end{tabular}

\section{RESULTS AND DISCUSSIONS}

\subsection{Estimating the EF and Bio-Capacity of Urban and Rural Household}

The estimation of EF of both urban and rural households in Minna Emirate was conducted to establish their EF and compare it with the dweller's lifestyles. The analysis determines the rate of regional consumption of natural resources available in the emirate. The Bio-capacity was also estimated. Table 2 shows the EF and Bio-capacity of the urban and rural areas, the table indicated that the urban EF was $1.10 \mathrm{gha} / \mathrm{capita}$ and the rural area has EF of $0.892 \mathrm{gha} / \mathrm{capital}$

Table 2: Sustainability Accounting (gha) of Urban and Rural Areas of Minna Emirate

\begin{tabular}{|l|l|l|l|l|l|}
$\begin{array}{l}\text { Consumption } \\
\text { Area (Demand) }\end{array}$ & EF Urban (gha) & EF Rural (gha) & $\begin{array}{l}\text { Bio-Capacity } \\
\text { Area (Supply) }\end{array}$ & Urban (gha) & Rural (gha) \\
\hline Food & 0.427 & 0.321 & Arable land & 0.60 & 0.67 \\
\hline Transportation & 0.236 & 0.232 & Grazing Land & 0.12 & 0.26 \\
\hline Housing & 0.186 & 0.134 & Built-up Land & 0.27 & 0.17 \\
\hline Energy & 0.172 & 0.145 & Forest Land & 0.09 & 0.13 \\
\hline Water & 0.065 & 0.050 & Fishing Ground & 0.07 & 0.04 \\
\hline Waste & 0.014 & 0.010 & Energy Land & 0.06 & 0.07 \\
\hline Total & 1.100 & $\mathbf{0 . 8 9 2}$ & & $\mathbf{1 . 2 1}$ & $\mathbf{1 . 3 4}$ \\
\hline
\end{tabular}

The EF of the urban and the rural Minna region shows that Food consumption accounts for 0.425 gha and 0.321 gha per capita respectively. The proportion of consumption of agro-food products to that of dairy food items (animal-based) is in the ratio of 30:70 in the urban area and 15:85 in the rural areas. Non-conventional energy sources such as Charcoal, fuelwood, and Kerosene for domestic energy consumption is a vital contributor to EF of energy in both urban and rural Minna emirate, because of inadequate and erratic electricity. Housing components of EF estimation (resource consumption for construction and embodied energy for its operation), hence the EF of the urban area ( $0.186 \mathrm{gha} /$ capita) is higher than the rural area ( $0.136 \mathrm{gha} / \mathrm{capital})$. This is a result of the utilization of imported building materials in urban areas while the rural area depends on indigenous building materials. Public transport, private car, motorcycle, and tricycles are the most commonly utilized as the mean of transportation in urban areas while the rural areas depend on motorcycles and trekking. Water consumption in urban areas and rural area differ in the quantity 
consumed and sources of the water. The urban areas depend more on public supply and boreholes while the rural area depends on streams and shallow wells. The consumption of potable water by residents of this region is lesser than the globally satisfactory standard. The current supply in urban Minna is 15.5 litres/capita/day while there is no public supply in the rural area. The supply is extreme lower to the standard stipulated by WHO of 60 litres/capita/day (WHO Standard as put forward by Bastinoni et al. [26]. The Ecological Footprint of waste in urban areas of the Minna region is higher than the rural Minna due to the composition of the solid waste and the level of biodegradable resources used. The method of management of waste in both urban and rural Minna regions is poor.

The Bio-capacity potentials of the urban and rural region show that all the components of the measurement of Bio-capacity are higher in the rural area. The underlining factor for this is the population size. The Bio-capacity, similar to EF is a function of the population as it is measured in per capita. Therefore, the potential of rural Minna to sustain their livelihood is higher than the urban area. Figure 3 shows the sustainability potential of the urban and rural areas of the Minna Emirate. The analysis shows that urban areas of the Minna region have lower sustainability potentials while the rural area has a high level of sustainability potential. The reason for differences in the potentiality is the lifestyle, the consumption pattern, the types of housing, energy usage, transportation mode, and the amount of waste generated by the dwellers of these neighbourhoods.

\subsection{Analysis of Components of EF in Urban and Rural Areas in Minna Emirate}

The analysis of the components of resources that produce the Ecological Footprint in both urban and rural areas of the Minna Emirate is shown in Figure 4. The result indicated that urban areas produce higher EF/capita in all the components than the rural area due to income level, the lifestyle that is superior to the rural area, and better quality of life in urban areas compared to rural areas.

Fig. 4: Components Ecological Footprints of Urban and Rural Minna Region
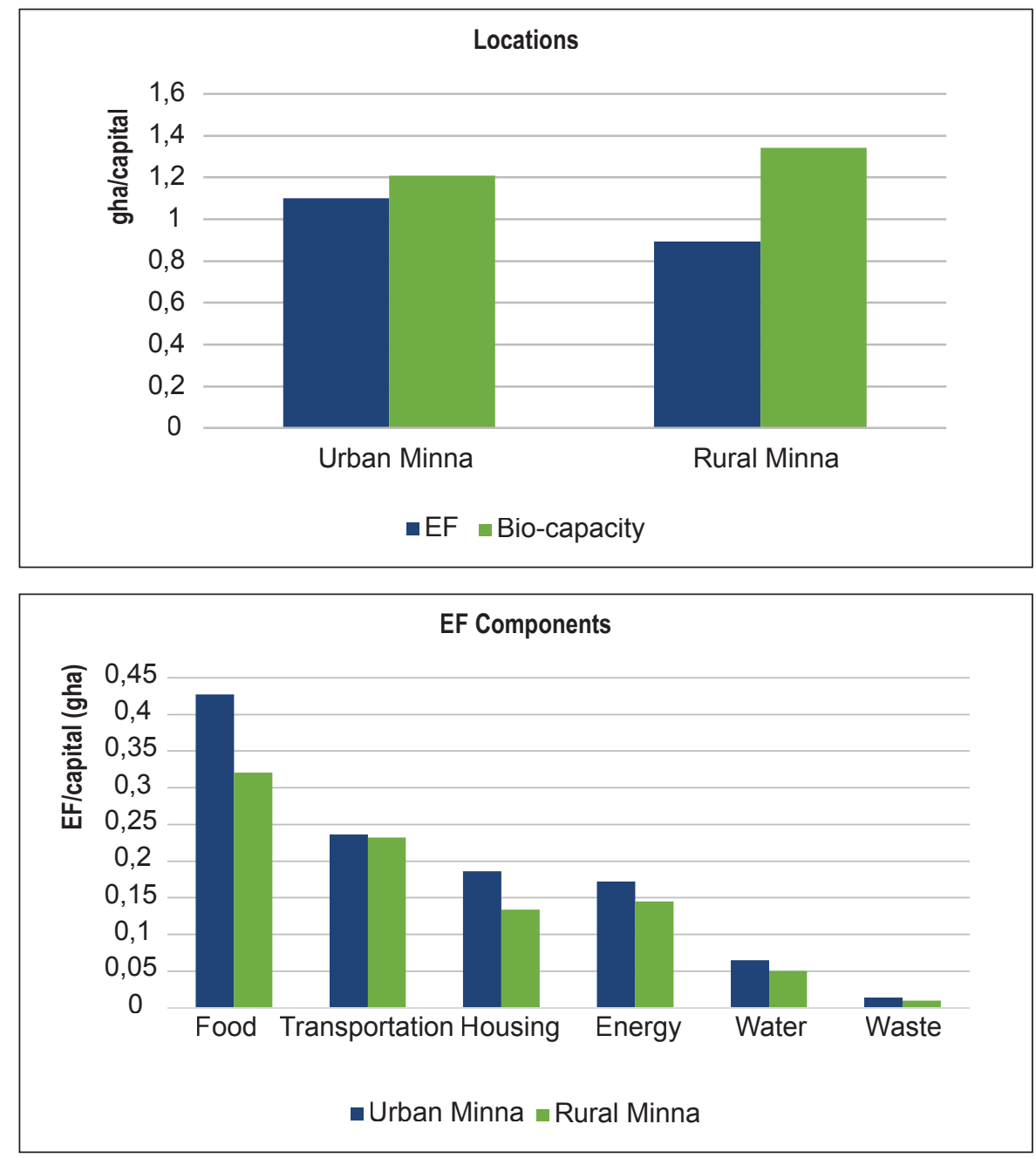


\subsection{Analysis of Components of Bio-capacity in Urban and Rural Areas in Minna Emirate}

The analysis of the components of Bio-capacity in Minna Emirate indicated that rural area produces higher regenerative potential due to low level of solid waste generation and small land areas used for buildings whereas the urban areas show the low level of bio-capacity. Figure 5 shows the components of Bio-capacity in urban and rural Minna Emirate.

Fig. 5: Components Bio-capacity Potential of Urban and Rural Minna Region

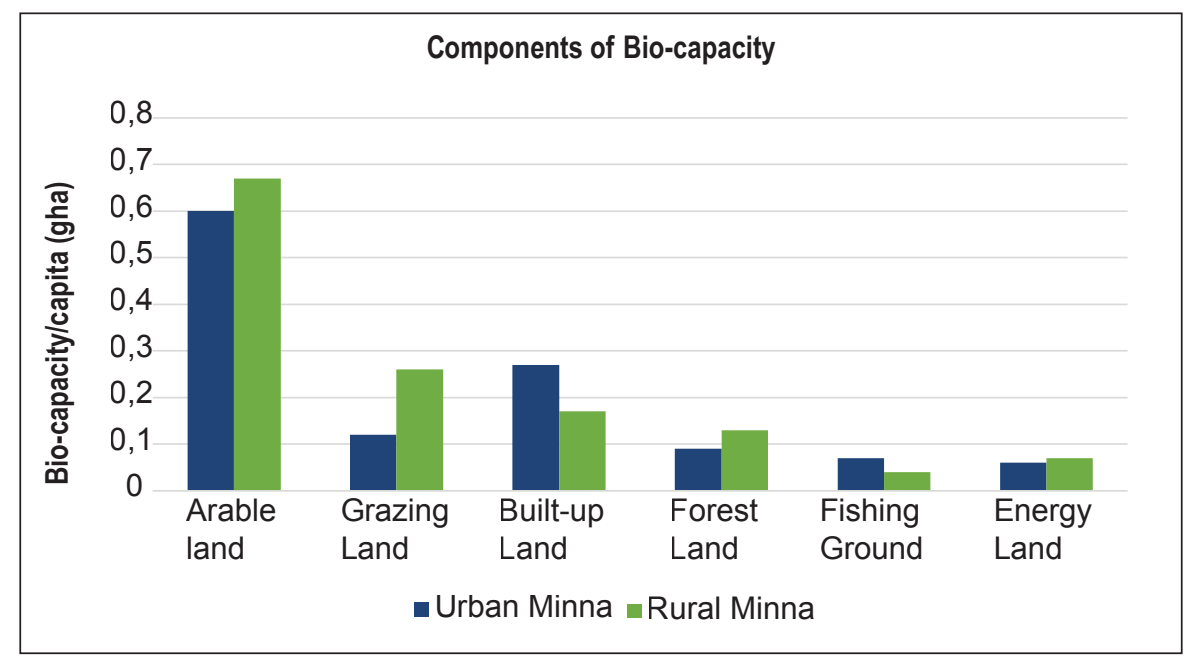

\subsection{Neighbourhoods Mean Ecological Footprint and CO2 Emission in Minna Region}

The analysis of the mean EF and CO2 emissions by households in different neighbourhoods in urban and rural Minna Emirate is presented in Table 3. There are little variations in the extent of $\mathrm{CO} 2$ emissions in all the neighbourhoods. The major contributor to the emission is the choice of the energy used for operating the house and the energy for cooking. Analysis of the findings shows that the average Ecological Footprint of the Minna Emirate was $1.096 \mathrm{gha} / \mathrm{capita}$ (1.10 gha/capital in urban areas and $0.89 \mathrm{gha}$ capital in rural areas). This implies that an average of 0.90 planets is required to sustain the current lifestyle and living standard of the residents of the Minna Emirate. The average $\mathrm{CO} 2$ emission per capita per annum in both urban and rural Minna Emirate was 6.2 and 4.3 tonnes respectively. The result in Table 3 shows the Ecological Footprint of different neighbourhoods in urban and rural areas of the Minna Emirate. The urban neighbourhoods produce higher EF and consume higher resources when compared with the Ecological Footprint of rural dwellers in the study. the analysis of EF of different neighbourhoods such as a Minna city centre is higher EF than the city's average. If this is compared with the other neighbourhoods of urban Minna, the consumption patterns are higher concerning different components such as transportation, food, energy, housing, waste generation, and water usage. Other neighbourhoods within the urban Minna were observed to have EF within the limit of the urban average. The study also revealed that the neighbourhoods at the urban fringes produce lesser EF. It was inferred that households in other neighbourhoods produce lesser EF because of the availability of public transport, poor living standard, and smaller household size. Another factor that reduces the EF at other neighbourhoods in the city and rural area includes household size, consumption pattern, and poverty level.

Table 3: Mean Household EF, Planets Required and CO2 Emissions in Minna Region

\begin{tabular}{|l|l|l|l|}
\hline Neighbourhood & Mean EF (gha) & Planets required & CO2 Emissions (Tonnes) \\
\hline Minna City Centre & 1.13 & 0.95 & 6.78 \\
\hline Barkin Sale & 0.95 & 0.92 & 6.23 \\
\hline Sauke Kahuta & 1.02 & 0.93 & 6.14 \\
\hline Chanchaga & 1.04 & 0.97 & 6.11 \\
\hline Bosso Town & 1.07 & 0.96 & 6.12 \\
\hline Maitumbi & 1.18 & 0.92 & 6.10 \\
\hline Maikunkele Village & 0.89 & 0.89 & 4.30 \\
\hline Mean (Minna Region) & 1.10 & 0.90 & 6.12 \\
\hline
\end{tabular}

Source: Author's Field Survey, 2019 


\section{ANALYSIS OF THE FACTORS INFLUENCING ECOLOGICAL FOOTPRINT IN MINNA EMIRATE}

The analysis of the factors influencing the Ecological Footprint and consumption of resources in the Minna Emirate was conducted through inferential statistics (multiple regression analysis). This involves analysis of different determinant factors influencing the EF estimates of households. The analysis was carried out in three stages; the first stage was for urban households, the second in rural households, and the third in the entire Minna Emirate. The analysis was conducted to determine which factors have a higher influence on the EF of the emirate.

\subsection{Regression Analysis Model for Factors Influencing Urban Households EF}

The analysis of the regression model for urban EF establishes the effect of different dynamics that control the EF of urban households. The result, as presented in Table 4 shows that the monthly income, household size, education, housing floor size, car ownership, gas fuel for heating, and waste generation are the contributing factors to the urban household positive impact on EF. The result shows that these factors are statistically significant to household EF. This result is corroborated by the findings of Ryan [21] that higher income has a significant effect on the consumption of resources and thereby has the potential to increase the EF of an individual or household. The implication is that household income influences the expenditure and consumption of resources within the urban neighbourhoods. The adjusted $\mathrm{r} 2$ shows that $83 \%$ of the variable determines the EF of the urban areas in Minna Emirate as-explained by the model.

Table 4: Results of Regression Analysis of the Factors Controlling EF of Urban Households in Minna Emirate

\begin{tabular}{|c|c|c|c|c|}
\hline \multirow{2}{*}{ Variable } & \multicolumn{4}{|c|}{ Unstandardized Coefficients } \\
\hline & B & Std. Error & $\mathrm{T}$ & Sig. \\
\hline (Constant) & 4.661 & .117 & 3.221 & .000 \\
\hline Household Monthly Income (HY) & 7.229E-007 & .000 & 21.663 & .001 \\
\hline Household Size (HS) & -.0451 & .007 & -6.558 & .001 \\
\hline Education Attainment (EDA) & .021 & .010 & 3.185 & .031 \\
\hline Household Floor Size (HFSD1) & -.121 & .026 & .574 & .008 \\
\hline Energy Efficient Appliances (EUD2) & -.055 & .054 & 2.157 & .133 \\
\hline LPG Appliances (EUD3) & .294 & .047 & 4.311 & .000 \\
\hline Organic Food Items (FUD4) & -.044 & .061 & .991 & .311 \\
\hline Commercially Packed Products (FUD5) & .033 & .066 & .388 & .551 \\
\hline Public Transport (MTD6) & .075 & .047 & 2.606 & .048 \\
\hline Own a Car (MTD7) & .255 & .012 & 9.557 & .000 \\
\hline Type of Employment (OCD8) & .042 & .041 & 2.992 & .051 \\
\hline Occupation (OCD9) & .065 & .081 & 2.723 & .059 \\
\hline Gas Fuel for Cooking (FHD10) & -.112 & .042 & 3.177 & .005 \\
\hline Electricity for Cooking (FHD11) & .072 & .051 & 2.601 & .125 \\
\hline Volume of waste (VW) & .044 & .033 & 3.117 & .019 \\
\hline Diagnostics & \multicolumn{2}{|l|}{$R=0.91$} & \multicolumn{2}{|c|}{ Adj. R2 0.83} \\
\hline
\end{tabular}

Dependent Variable= Ecological Footprint of Urban Household (HEF).

The result revealed that factors such as household size indicated a negative effect on the Ecological Footprint of residents of urban areas. The model proved that it is statistically significant as an increase in urban households size with constant income can lead to lower EF. The work of Ruzevicius [27] and Bastianoni et al [2] agreed with this finding on household size and EF. The result of the educational factor also presents a positive influence on the Ecological Footprint in the urban Minna Emirate, it was found to be statistically significant. It is a known fact that higher educational attainment improves the income level and quality of life that of such an individual, this then aggravated the EF of the urban areas. Abd' Razack et al. [11] in their study showed that the standard of living in the urban Minna Emirate is the factor responsible for higher consumption of resources and higher EF. 
Available floor area per household and low energy consumption appliances indicate a negative relationship with the Ecological Footprint of residents of urban neighbourhoods. The use of LPG produces a positive impact on the urban household's, therefore it translated that it is statistically significant. On the other hand, organic food items produce a negative effect on the Ecological Footprint in the urban Minna Emirate. The urban dweller in Minna Emirate depends more on commercially packaged food items thereby increasing their EF. Public transportation shows an affirmative influence on the Ecological Footprint, this is because of the poor urban mass transit system and dependence on private cars by the residents. The use of the private cars is statistically significant and increases the EF. The research of Wiedmann et al. [29] agreed with these findings that driving private cars results in higher EF and Carbon emissions. Types of employment and occupation also have a positive effect on the Ecological Footprint of households in the urban Minna Emirate. The use of LPG as a domestic energy source for cooking by the residents of urban neighbourhoods produces a negative influence on EF; the result shows a significant relationship. The result also revealed that the amount of solid waste produced by households in urban Minna Emirate indicated a positive effect on the Ecological Footprint, it revealed that it is statistically significant. The households in the urban area generated between $0.64 \mathrm{Kg}$ and $0.56 \mathrm{Kg}$ per capita per day in Minna Emirate. The volume of waste generated increases as the population concentration increases. One of the hallmarks of urban Minna is the teeming population. Abd' Razack, et al. [11] agreed that a higher volume of solid waste produced by households in urban Minna Emirate contributed significantly to its EF.

\subsection{Regression Analysis Model for Factors Influencing Rural Households EF}

The analysis of the regression model of EF of rural Minna Emirate was conducted to establish the impact of various factors that contributes to EF of rural households in Minna Emirate. The result as presented in Table 5 indicated that six (6) factors: monthly income, household size, housing floor area, occupation, organic food items, types of employment, and waste generation contributed immensely to rural household's EF. This implies that the household income influences the expenditure and consumption of resources within the rural areas. The adjusted $\mathrm{r} 2$ shows that $88 \%$ of the variable determining the EF of the rural areas in the Minna Emirates are explained.

Table 5: Results of the Regression Analysis of the Factors Controlling EF of Rural Households of Minna Region

\begin{tabular}{|l|l|l|l|l|}
\multirow{2}{*}{ Variable } & \multicolumn{4}{l}{ Unstandardized Coefficients } \\
\cline { 2 - 5 } & $\mathrm{B}$ & Std. Error & T & Sig. \\
\hline (Constant) & 3.166 & .221 & 4.556 & .002 \\
\hline Household Monthly income (HI) & $4.111 \mathrm{E}-007$ & .010 & 18.222 & .005 \\
\hline Household Size (HS) & .033 & .027 & 2.666 & .007 \\
\hline Educational Attainments (EDA) & .091 & .080 & 1.555 & .061 \\
\hline House Floor Size (HFSD1) & -.144 & .032 & .741 & .010 \\
\hline Energy Efficient Appliances (EUD2) & .088 & .094 & 1.577 & .185 \\
\hline LPG Appliances (EUD3) & .334 & .072 & 5.112 & .060 \\
\hline Organic Food Items (FUD4) & -.032 & .031 & .771 & .001 \\
\hline Commercially Packed Products (FUD5) & .063 & .097 & .881 & .021 \\
\hline Public Transport (MTD6) & .053 & .027 & 1.999 & .028 \\
\hline Own a Car (MTD7) & .559 & .072 & 7.733 & .066 \\
\hline Type of Employment (OCD8) & .022 & .021 & 1.229 & .011 \\
\hline Occupation (OCD9) & .077 & .063 & 3.323 & .031 \\
\hline Gas Fuel for Cooking (FHD10) & .772 & .091 & 2.787 & .076 \\
\hline Electricity for Cooking (FHD11) & .672 & .081 & 1.771 & .205 \\
\hline Volume of waste (VW) & .034 & .011 & 2.223 & .011 \\
\hline Diagnostics & R=0.94 & & Adj. R2 0.88 & \\
\hline
\end{tabular}

Dependent Variable= Urban Household Ecological Footprint HEF.

The result from the findings shows that the number of people per household produces a positive influence on the Ecological Footprint of rural areas in Minna Emirate and the regression model signified that there is a significant statistical correlation between Ecological Footprint and household size; it implies that increase in rural household size usually leads to lower EF. The work of Ruzevicius [27] agreed with this finding on household size and EF. Housing floors size also has a significant correlation with the EF. Organic food items produced a negative influence on the Ecological Footprint in rural areas of the Minna Emirate 
as a large chunk of food in the rural areas is obtained from farms. The consumption of organic food items lessens the EF. There is also negative statistical significance between EF and commercially packaged food products because less of such products are consumed in rural areas. The rural dwellers have less apathy for packaged goods due to the cost and availability of fresh farm products. Occupation of the rural dweller also correlated with their EF because of monotype of occupation (farming). Rural households generated between $0.44 \mathrm{Kg}$ and $0.40 \mathrm{Kg}$ per capita per day of solid waste in the Emirate. The volume of waste generated is lower than in urban areas because of the lower population and use of biodegradable materials. On the contrary, the result of the educational factor does not correlate with the impact of EF on rural households. The educated elite among the rural dwellers found their way to the urban centres. This implies that as the educational attainment of rural dwellers improves, the income level and quality of life also improves. Energy-efficient appliances also do not correlate with the EF of rural households because they depend on the unconventional sources of energy such as wood fuel, charcoal, and sawdust. The use of LPG appliances also does not correlate and hurts the Ecological Footprint of households in rural areas of the Minna Emirate. Public transportation shows a positive influence on the Ecological Footprint of households in a rural areas, this is because rural dwellers in the emirate depend on motorcycles, trekking for their transportation and therefore contributed lower EF.

\subsection{Analysis of the Factors Influencing the Ecological Footprint of Rural Household in Minna Emirate}

The regression model for analysis of factors influencing the household EF in the Minna Emirate is presented in Table 6. The finding shows that monthly income positively influences EF and it has a statistical significance on household EF. The study revealed that enhancement of household income aggravates the consumption of resources, this invariably increases the households' EF. Wilson and Anielski [30] in their study revealed that there is a positive relationship between income and EF as found out in this study. The result indicated that household size has a negative effect and has a statistical significance to HEF. This implies that as the household size increases, especially in rural households where population check is negligible, the compound Household Ecological Footprint increases but individual EF in the long run reduces. The analysis revealed that as household energy consumption, resource utilization, transportation, and built-up area available per capita is distributed to every member of the households; then the EF impact was reduced. The consequence of this large population is waste generation. A high level of consumption of resources and waste generation has a negative effect on the environment. The result of this study corroborated the finding of Ruzevicius [27].

Table 6: Regression Analysis of Variables Influencing Rural Household EF in Minna Emirate

\begin{tabular}{|c|c|c|c|c|}
\hline \multirow{2}{*}{ Variable } & \multicolumn{4}{|c|}{ Unstandardized Coefficients } \\
\hline & B & Std. Error & $\mathrm{T}$ & Sig. \\
\hline (Constant) & 4.216 & .112 & 33.055 & .000 \\
\hline Household Monthly income (HI) & 7.775E-007 & .002 & 22.202 & .001 \\
\hline Household Size (HS) & -.062 & .006 & -4.422 & .000 \\
\hline Educational Attainments (EDA) & .044 & .010 & 4.661 & .004 \\
\hline House Floor Size (HFSD1) & -.067 & .041 & -1.616 & .002 \\
\hline Energy Efficient Appliances (EUD2) & -.017 & .048 & -.516 & .231 \\
\hline Gas Appliances (EUD3) & .314 & .044 & 7.121 & .000 \\
\hline Organic Food Items (FUD4) & -.007 & .022 & -.355 & .412 \\
\hline Commercially Packed Products (FUD5) & .035 & .045 & .538 & .114 \\
\hline Public Transport (MTD6) & .049 & .061 & 3.411 & .002 \\
\hline Car Ownership (MTD7) & .107 & .012 & 10.151 & .000 \\
\hline Type of Employment (OCD8) & .040 & .019 & 2.101 & .042 \\
\hline Occupation (OCD9) & .066 & .022 & 1.857 & .007 \\
\hline Gas Fuel for Cooking (FHD10) & -.073 & .051 & -1.556 & .009 \\
\hline Electricity for Cooking (FHD11) & .065 & .033 & 2.011 & .012 \\
\hline Volume of waste (VW) & .059 & .031 & 2.226 & .064 \\
\hline Diagnostics & R2 0.92 & & Adj. R2 & \\
\hline
\end{tabular}

Dependent Variable= Household Ecological Footprint HEF. 
Education as a variable of household contributed to EF, which has a positive effect on HEF; this is because as the level of educational attainment improves, the quality of life is enhanced. The educational level of people in rural areas of the Minna Emirate has also improved over time, because of the presence of basic and post-basic schools in the rural areas. The consequential effect of this is an increase in HEF. Abd'razack, et al. [11] also established that as the lifestyle of people improved, the level of consumption of resources also increases. The floor area occupied by households in the rural area in Minna Emirate shows that it has a negatively effect on HEF because as the population of the people in rural areas of Minna Emirate increases because of poor birth control, the HEF reduces. The urban households in parts of Minna Emirate living in a multi-storied dwelling and communal living have a similar effect. This consequently reduces the EF and optimize the land area needed for the construction of buildings in both urban and rural areas. The work of Bastianoni et al. [26] corroborated this result, as their findings show that compact development of urban space is a panacea for urban sprawl and reduction of EF. The utilization of energy-efficient appliances by households reduces the HEF, the extent of using of this types of appliances in the rural areas are minimal in Minna Emirate, therefore energy usage contributed significantly to the HEF. The result from the regression model for this study revealed that the factors that influence the HEF in rural Minna Emirate show hitches in heteroscedasticity. This was discovered during the analysis of the data obtained from the selected household for the study. Therefore WLS model was employed to correct the animalizes identified during the analysis.

The usage of gas appliances by the households in Minna Emirate is a factor in the enhancement of the Household Ecological Footprint. Agricultural process of planting and harvesting of non-animal food items in the locality follow the traditional methods, though this reduces the HEF it is mostly practiced in the rural area of the Emirate; the situation is different in urban Minna Emirate because a large proportion of urban dwellers depend on the commercially packaged food items for their living, thereby increasing the HEF. The extent of purchase of imported goods (either animal or non-animal food items) and utilisation of unsustainable means of public transportation also affected the HEF. The usage of the private transportation system is high in Minna Emirate because of the poor state of public transport and social status. This has a positive impact on HEF. The poor usage of public transport was due to poor road system, the poor fleet of vehicles, non-availability and ineffective public transport services. The usage of petrol and diesel as a source of energy for taxis and buses enhances the Ecological Footprint of the Minna Emirate. This study agreed with the work of Wiedmann, et al. [19] that the higher EF occur in cities as a result of high dependence on private vehicle at the expense of public transport. The type of employment and occupation also contributed positively to the HEF, a better occupation and tenure employment enhances the quality of life of the household and this has a higher impact on consumption of resources and increases the HEF. The use of LPG and electricity for domestic energy consumption by the household for cooking reduces the Household Ecological Footprint. The study revealed that this is statistically significant, but the use of non-conventional sources of energy in rural areas enhances the HEF. The result of the study on the volume of waste generated by households indicated that it has a positive impact on EF. The coefficient of the relationship of the volume of waste generated and HEF showed a significant statistical relationship. This is in line with the findings of Abd'razack, et al. [11] that a higher volume of solid waste produced by households has an impact on HEF and causes ecological imbalances.

\section{CONCLUSION AND POLICY RECOMMENDATIONS}

The analysis presented above shows the comparative relationship of Ecological Footprints between urban and rural households in the Minna Emirate in North Central Nigeria. They employed the following components of EF: food, transportation, housing, energy, waste, and water consumption. The effect of these consumptions components on the ecological balance of the Emirate was considered. The influencing factors that have a direct impact on the EF of households in urban and rural neighbourhoods were estimated using the EF calculator, Bio-capacity of the existing land (CLUM), and Econometric Modelling analysis was conducted. The major findings are given as under:

The study revealed that 0.91 and 0.74 planets are required by individuals in the Emirate based on the current lifestyle in urban and rural Minna emirate. It also produces average $\mathrm{CO} 2$ emissions of 6.2 and 4.3 Tonnes per annum. This indicated that higher EF in urban was a result of income, improved standard of living, lifestyle, mode of transport, and energy usage. Therefore the urban dwellers need to change their habits to reduce the EF.

The urban populace in Minna needs to reduce their solid waste by using biodegradable packaging and embraces the use of recycling and re-using materials to reduce the solid waste in the city and hence improve on the environmental upgrade.

Mode of transportation and distance traveled by the urban dwellers has to use better transportation means such as urban public transport rather than private cars and the use of conventional energy source will reduce the EF of the households. increases their EF compared with rural areas dwellers who treks and travel short distances. 
The deduction from the study was that the urban households in Minna Emirate produce higher EF than a rural area, therefore, the households residing in the urban areas of Minna Emirate need the additional amount of global hectares of land when in comparison with households in rural areas. The level of consumption of resources in urban neighbourhoods is higher than the rural areas because of higher income, educational attainments, and improved standard of living. On the other hand, households in rural areas do not have access to the higher number of resources and produce higher quantities of non-animal-based food items. Therefore the rural households in Minna Emirate consume fewer animal food items and resources that reduce their per capita Ecological Footprint. The major contributing factors to EF in both urban and rural regions are food and energy. Food consumption in the Emirate and usage of non-conventional energy sources for cooking and private vehicle usage directly impact the EF. Though the EF of Minna Emirate is slightly sustainable at the moment, there is no absolute sustainability because of population increase. This has the potential to triggers change in EF and the city becomes unsustainable. Therefore, policymakers must not be complacent. There is the need to reduce the consumption pattern and lessen the pressure on ecological reserves of the Emirate and also decrease the level of emission of greenhouse gas that is a panacea for the sustainability of the Emirate.

\section{RECOMMENDATIONS}

As observed from the study, it is pertinent to recommend the following as a way out to sustainable development of the region:

- The Government at the local level of the region have to sensitize the populace of the region on their present demand on ecological resources and its effect on sustainability and the effect of the choice of energy that shows the emission level in the region compared with the permissible level of emission that can enhance the sustainability of the region in particular and Nigeria in general.

- $\quad$ The government at all levels and the agencies should encourage the production of locally produced organic food items and reduction in the consumption of imported packed food items to enhance local production and reduced the transportation EF.

- Policymakers, educationists and environmentalists should provide proper education on the importance of efficient solar fitted buildings to reduce the usage of hydrocarbon and support for local food industries and promoting local agriculture to produce non-animal food items and urban agriculture to boost food production in the region. Urban agriculture assists in reducing urban temperature and protects the urban green spaces.

- Policy-makers should enable programs that encourage households to reduce their footprint is vital such as the usage of the public mass transit vehicle at the expense of private cars; bicycle lanes could introduce to urban planning to reduce the usage of hydrocarbon driven cars.

- $\quad$ Agricultural extension workers should provide technical/extension services to local farmers that will help local farmers and formulated policies and agendas by the government incorporated them into a food supply system that will reduce dependency on imported processed food items.

- $\quad$ Furthermore, considerations have to be given to reduce environmental impacts of the usage of non-conventional energy sources for cooking and reduction in private transportation by improving on the urban mass transport system. This is because they contributed immensely to EF.
- $\quad$ Planting trees that is environmentally friendly around the dwellings will reduce the effect of climate change. This can provide natural air cooling and shade for the residents and healthy living

- Also, households have to be informed about the use of energysaving appliances in the house to reduce costs and energy used. The use of natural lightning of sunlight as much as possible should be encouraged.

- $\quad$ Proper education on the conservation and water usage by the households should be encouraged as this will lower ecological impacts on the environment and reduce the cost of obtaining water by the government agency saddled with the responsibility of providing water to people.

\section{REFERENCES}

[1]. GFN (2010). Ecological Footprint Atlas, 2010. Oakland, California, USA: Global Footprint Network.

[2]. Norbet, M. \& Peter, W. (2010). Urban Biodiversity and the Case for Implementing the Convention on Biological Diversity in Towns and Cities In Norbert, M., Peter, W. \& John, G. K. (Eds.) Urban Biodiversity and Design (pp. 1-3). Chichster, UK Wille-Blackwell:

A John Willey Publication Conservation Science and Practice Series.

[3]. UN-Habitat (2008). State of the World's Cities 2008/2009. London Earthscan. Available at www. unpfa.org Accessed on 15th April 2014

[4]. EPSM. (2007). Take care of the Earth before it's Gone. Environmental Protection Society of Malaysia publications

[5]. Newman, P. (2006). The Environmental Impacts of Cities. Environment and Urbanization 18 (2): pp275-295 
[6]. Wackernagel, M. and W. Rees (1998). Our Ecological Footprint: Reducing Human Impact on the Earth: New Society Publishers.

[7]. Ayres, R. U. (2000). Commentary on the Utility of the Ecological Footprint Concept: Discussion in the Ecological Footprint Forum. Ecological Economics. 32 (3): pp359-362.

[8]. Bagliani, M., Galli, A., Niccolucci, V. and Marchettini, N. (2008). The Ecological Footprint Analysis Applied to a Sub-national Area: The case of the Province of Siena (Italy). Journal of Environmental Management. 86 (2): pp354-364.

[9]. Wiedmann, T. (2009). First Empirical Comparison of Energy Footprint Embodied in Trade MRIO versus PLUM Ecological Economics 68: pp 1975-1990.

[10]. Holden, E. (2004) Ecological Footprints and Sustainable Urban Form. Journal of Housing and the Built Environment, 19 (1): pp 91-109.

[11]. Abd' Razack, N.T, Ludin, A.M. and E. Umaru (2013) Ecological Footprint, Lifestyle and Consumption Pattern in Nigeria. American-Eurasian Journal of Agriculture and Environmental Science 13 (4): pp 425-432

[12]. Wackernagel, M. (2001) Advancing Sustainable Resource Management: Using Ecological Footprint Analysis for Problem Formulation, Policy Development, and Communication.

[13]. Wackernagel, M. and Rees, W. E. (1997). Perceptual and Structural Barriers to Investing in Natural Capital: Economics from an Ecological Footprint Perspective. Ecol. Econ. 20: pp 3-24.

[14]. Adams, W. M. (2006). The Future of Sustainability: Re-thinking Environment and Development in the Twenty-first Century. The IUCN Renowned Thinkers Meeting
[15]. Dobson, A. (2007). Environmental Citizenship: Towards Sustainable Development. Sustainable Development 15(6): pp 276-285.

[16]. Abd'Razack, N.T.A (2014). Ecological Footprint as an Assessment Tool for Sustainable Urban Development in Minna, Nigeria. An Unpublished Ph.D. Thesis in the Department of Urban and Regional Planning. FakultiAlam Bina, UniversitiTeknologi Malaysia

[17]. Oloruntegbe, K., T. A. Oluwatelure, and O. Agbayewa (2013) Eco-Cultural Factors and Ecological Footprint as Variables and Measure of Environmental Consciousness and Accounting in Nigeria. Journal of Education and Practice 4 (16): pp 91-94.

[18]. Ewing, B., Reed, A., Galli, A. Kitzes, J. \&Wackernagel, M. (2010) Calculation Methodology for the National Footprint Accounts. Oakland: Global Footprint Network.

[19]. Wackernagel, M., Schulz, N. B., Deumling, D., Linares, A. C., Jenkins, M., Kapos, V., Monfreda, C., Loh, J., Myers, N., Norgaard, R. and Randers, J. (2002). Tracking the Ecological Overshoot of the Human Economy, Proceedings of the National Academy of Science 99: pp 92669271.

[20]. Kitzes, J., A. Peller, S. Goldfinger, and M. Wackernagel (2007) Current Methods for Calculating National Ecological Footprint Accounts. Science for Environment and Sustainable Society 4(1): pp 1-9.

[21]. Ryan, B. (2003). Ecological Footprint Analysis: A Comparison between a Rural Village and EcoVillage Footprint. M.Sc. Thesis, Dublin Institute of Technology, Dublin.

[22]. GFN (2016). African Ecological Footprint Trends, 2016. Available at: http://www.footprintnetwork org/med/index.php/GFN/page/ footprint_African_EF_Trend/ (Accessed on April 1, 2018).
[23]. NPC. (2011). 2006 Population and Housing Census: Administrative Report. Abuja, Nigeria: National Population Commission, Publication Unit, Presidency.

[24]. Minna Master Plan (1980). The Master Plan for Minna 1979-2000: Final Report. Town Planning Division, Ministry of Housing and Environment, Niger State. Max Lock Group, Kaduna, Nigeria.

[25]. Cresswell, J. W. (2012). Educational Research Planning: Conducting and Evaluating Qualitative and Quantitative Research. (4th Ed.) New York, USA: Pearson Publishers.

[26]. Bastianoni, S., A. Galli, V. Niccolucci, and R. Pulselli (2006). The Ecological Footprint of Building Construction. The Sustainable City IV: Urban Regeneration and Sustainability, 345-356.

[27]. Ruzevicius, J. (2011). Ecological Footprint: Evaluation, Methodology and International Benchmarking Journal of Current Issues of Business Law 6 (1): pp11-30.

[28]. Bastianoni, S., Galli, A., Niccolucci, V. and Pulselli, R. M. (2006). The Ecological Footprint of Building Construction In Mander, U., Brebbia, C. A. \& Tiezzi, E. (Eds.) The Sustainable City IV: Urban regeneration and sustainability (pp. 345-356). Southampton, UK: WIT Press.

[29]. Wiedmann, T., Minx, J., Barrett, J. and Wackernagel, M. (2008). Allocating Ecological Footprints to Final Consumption Categories with Input-Output Analysis. Ecological Economics. 56: pp 2848.

[30]. Wilson, J., and M. Anielski (2011) City of Saskatoon Ecological Footprint Analysis. The City of Saskatoon, Community Services Department, Planning and Development Branch, Anielski Management Inc. 